City University of New York (CUNY) CUNY Academic Works

2012

\title{
A Kitchen of One's Own: The Paradox of Dione Lucas
}

Kathleen Collins

CUNY John Jay College

\section{How does access to this work benefit you? Let us know!}

More information about this work at: https://academicworks.cuny.edu/jj_pubs/2

Discover additional works at: https://academicworks.cuny.edu

This work is made publicly available by the City University of New York (CUNY).

Contact: AcademicWorks@cuny.edu 


\section{A Kitchen of One's Own: The Paradox of Dione Lucas}

Julia Child, whom many consider to be "the mother of French cooking in America," actually bestowed this title on Dione Lucas, ${ }^{1}$ a fellow cooking teacher who appeared on television well over a decade before Child hosted The French Chef. Her television cooking program, The Dione Lucas Show, was on the air from $1947-56,{ }^{2}$ and it reveals a largely neglected slice of American television and food history. The reason for the show's eclipse is partly due to the subsequent arrival and reign of Julia Child and contemporaneous attending cultural forces, yet it is also a result of Lucas' incongruity with the conventions of her era.

Most of the scholarship on food television over the past fifteen years has focused on recent cooking shows, but Lucas' contribution to culinary and television history is significant and worthy of resurrecting. Through considering the persona of Dione Lucas, I will investigate the rituals and expectations of the television cooking show genre (both pre-lifestyle, pre-Julia Child television as well as present fare) and elaborate on how their observance (or contravention) helps us to understand their impact on viewers' habits and perceived societal norms and their meaning, i.e. their explicit and implicit instructions on how to play proscribed roles or aspire to cast them off.

The fact that the presentation of cooking instruction coincided with the advent of broadcasting - first radio then television - may be construed as validation of its elemental cultural position and/or as a fulfillment of public (i.e. women's) service. However, the best explanation for the ubiquity of early cooking programs is a commercial one: program sponsors wished to sell products. Cooking shows were inexpensive and simple to produce, and they offered an ideal vehicle for selling food, appliances and utilities. Such prosaic motivation, however, does not preclude an exploration of the cultural meanings presented. Any television program has a potential societal effect as well as serving as a mirror, and cooking programs have 
a unique relation to attitudes about gender norms, work and overall cultural tastes. Because television cooking programs have been on the air in the U.S. for over six decades, their evolving content and formats provide a longitudinal view on our changing habits and values.

Cooking has traditionally been understood as a function mainly executed by women for the purpose of feeding self and others - namely, family. At the time of the airing of The Dione Lucas Show, the ritual of cooking or even of the teaching of cooking had already been accepted and understood (though perhaps not examined) by television viewers. Radio cooking instruction had been in existence since the late 1920s, but the visual performing aspect was an entirely new proposition. In 1947, when Lucas first emerged on screen, the notion of a television cooking program (or of any program) was an innovation, and therefore the ritual of the genre had not yet been fully incorporated into popular or media culture.

Cooking show hosts perform in public rituals that are normally done in the privacy of one's own home. A natural routine behavior is thus rendered unnatural, but the artificiality - a host narrating her actions, taking pains to face in the direction of the camera, calling upon preprepared or pre-cooked ingredients, finding an already finished cake in the oven - is abated by the setting which usually resembles (or in some cases is) an actual home kitchen. The host is therefore required to be skilled in both cooking and performing, though the degree to which these skills are met varies widely.

The European-born and -raised Dione Lucas learned to cook non-professionally at home for parents and siblings, but she soon discovered cooking as an art rather than as a mere domestic task. "There is a tendency to whisk in and out of the kitchen, to be lured by dishes that can be made most quickly," she wrote in The Cordon Bleu Cook Book. "Cooking cannot be relegated to the same category as dishwashing or making beds." ${ }^{3}$ Taking the art seriously, consequently, she was one of the first female graduates of the Cordon Bleu culinary school in Paris in the 1930s. 
She moved to the United States during World War II and opened a popular cooking school and restaurant in New York City. Upon bringing her teaching and cooking schools to the airwaves, she became more widely known and hers was one of the first cooking shows aired nationally on television in the U.S.

The Dione Lucas Show (originally titled To the Queen's Taste when it was first aired as a local CBS program in New York City) was sponsored by the Caloric Appliance Corporation and by various gas companies around the U.S. Its ostensible purpose was to provide cooking instruction to viewers. In this way, it was not different from the other cooking programs broadcast during the 1940s and 50s, most of which were produced and aired locally and hosted by home economists or local TV personalities. With titles like Homemaker's Exchange, Menu Magic, and Homemaking with KSD-TV, these programs reinforced gender norms as well as the “culinary gridlock" that food historian Harvey Levenstein describes as characterizing the 1950s' food landscape. ${ }^{4}$ Conforming and convenience were, if not buzz words, then buzz motivators of the time period. "According to many promotional and privately authored cookbooks [in the late 1940s and 1950s], a myriad of new household appliances and new canned, packaged, and frozen foods had ushered in an age of push-button ease," writes historian Jessamyn Neuhaus. Women were finally being set free - by technology - from the traditionally laborious task of cooking, and the enterprise was given less time in both the execution and in the imagination. To spend much time at all in the kitchen was passé. Therefore the major role of cooking programs was to teach women about new timesaving techniques, recipes, and products.

In its structure The Dione Lucas Show shared the traditional elements of the genre: the original "dump and stir" format before there was anything else to which it could be compared and long before reality, competition, and travel subgenres appeared. There was just the simple narrative - gathering ingredients, preparing and combining ingredients, cooking and presentation 
- accompanied by a host verbally outlining the procedures. A number of factors set Lucas apart from her contemporaries, however, and the food she prepared was one of the more salient. Rather than embrace and promote the convenience processed foods du jour (e.g. canned soups, sauces and gravies, cake mixes, frozen vegetables), she prepared relatively exotic, mostly French, dishes from fresh foods. On one episode, she prepared a whole bass, something audiences would not likely see anywhere else on TV in the 1950s and not again until Julia Child had her way with fish and more starting in 1963. Though, in later years, Lucas developed a line of canned soups, throughout most of her show, such "push-button" components were nonexistent. She did not verbally eschew such conveniences but rather ignored their existence.

To compound her oblique flouting of convenience foods, Lucas presented relatively timeconsuming, advanced recipes. She was able to make them look deceptively foolproof due to her skill, but many viewers in the 1950s would likely be unwilling or unable to replicate them. She did not address the issue of time, however, and was not catering to the busy housewife or growing ranks of women working outside the home. Watching Dione Lucas today, a viewer might succumb to the "nostalgia for an imagined past" described by Elizabeth Nathanson, "in which women had endless amounts of time to devote to their domestic responsibilities." Nathanson also observes that "the contemporary [i.e., today's] home is defined by a unique form of 'postfeminist' temporality in which the logic of the working world is appropriated by and adapted to the rhythms of the private sphere." In the early 1950s, such temporality (or second wave and therefore "post" feminism) had yet to be conjured. Vocabulary including "crazy busy," "time crunch," or even the concept of a harried working mother was not yet a fixture of modern life. In 1950, however, a third of American women were participating in the labor force. ${ }^{8}$ Perhaps watching Lucas at the time of the show's broadcast would lead some homemakers to envy what seemed like inordinate amounts of free time to cook creatively on Lucas' part. Nevertheless, she 
was not misleading in her actions. Cooking was her primary occupation. Unlike the majority of her female viewers, many of the other responsibilities she had in her life off-camera likely had to do with her role as a businesswoman. She offered no clue, however, that she herself was a housewife or mother (she was, in fact, the sole parent of two young boys) or that members of her audience were.

Lucas' closest descendant in the genre is Martha Stewart, who was also out of step with her peers when she first appeared on television in the 1980s and, in many ways, continued to be so into the 1990s. As Americans embraced the microwave oven and high-end restaurant dining, Stewart enjoined them to head back to the kitchen, if not back to the farm and to artisanal crafts of all sorts. Notably, Lucas and Stewart also share an air of remoteness and sophistication, potentially intimidating skill, and modest clothing (in contrast to other women hosts such as Giada De Laurentiis and Rachael Ray). Both advocate cooking as an art and, implicitly, as a means of self-fulfillment. ${ }^{9}$ Lucas and Stewart were/are aspirational figures.

In addition to situating herself in opposition to the convenience-happy attitude of her era, Lucas was an outlier with regard to temporality on a number of levels. Her anachronistic culinary methods could be perceived as out of place or in stark contrast to the ultra-modern medium of TV; though, as her show was first broadcast in 1947, her performance there was a novelty for her and her viewers and therefore unlikely to be subject to such meta-observation. Her acknowledgment of being on television was nonchalant: "This particular soup takes anything up to 45 minutes to brown," she says in her onion soup episode, "because the slower you brown it the better your soup's going to be. So naturally we can't wait around 45 minutes, knowing this is television and whatnot, so we've got some already made."

More inconsistent with the era was the fact that the show was broadcast during prime time, and though James Beard (whose cooking show I Love to Eat premiered nationally on NBC 
a year prior to The Dione Lucas Show) had also been shown during the evenings, it was highly unusual for a cooking program to be so. The traditional relationship constructed with cooking programs is that between the host (who was usually female and usually operating alone on camera) and the audience. In the 1940s and 50s, the intended target of most cooking programs was housewives. This is to whom the content of the program and the sponsor information were directed, and, accordingly, programs generally aired during the daytime. A number of scholars have commented on the ways in which women's programming was designed to correspond to the rhythm of a housewife's day. ${ }^{10}$ As Robert Hammel Stewart wrote of the women's daytime variety program format, "[A]long with the slower pace is a lesser emphasis on the visual aspects of the program. The housewife can do her work while she listens and enjoys the program without the insistent demand that she also watch imposed by visual antics." ${ }^{, 1}$ This does not hold true, however, for cooking instruction, for which the visual antics are the main reason purposefully to watch. Nor does it hold true for many viewers of The Dione Lucas Show.

Who, then, was the audience for Dione Lucas? While housewives were the traditional intended audience of such shows and may have watched The Dione Lucas Show, they were not doing so during the traditional daytime slot. ${ }^{12}$ Because Lucas offered a more sophisticated array of recipes than other homemaking shows and because her program heavily promoted appliances and utilities, the men and working-force women who watched at night were, practically speaking, a target segment as well. Households with higher incomes, and therefore more likely to have a television set, were also of likely interest to the show's sponsors. Along with higher incomes, sponsors might have deduced, come more refined tastes. Unlike most of the home economics and women's service programs on during the time period, Lucas prepared urbane dishes more likely to be served at dinner parties than at the weeknight family dinner table. In making mostly European food, she would often begin a suggested instruction with, "In France 
they...." Her European background and accent compounded the foreignness, an aspect that was at odds with the strong sense of American patriotism surging through the postwar, Cold War U.S. during the time she was on the air. French cuisine was still quite unusual to most people in the U.S., and while Lucas presented it frequently, it was not until Julia Child did so - at the same time that the Kennedys employed a French chef in the White House - that French cuisine began to present itself as a noticeable trend in the U.S. All of these factors made Lucas unusual in relation to her TV peers and in the media context.

Despite her somewhat dated trappings, Lucas was actually ahead of her time in several ways. In addition to French food, she incorporated many other ingredients that were not part of a standard American diet - e.g., globe artichokes, olive oil, garlic, anchovies - but that would become common, if not staples, in due course. Both James Beard and Lucas were out of sync with their peers and unknowingly ahead of their time in their attitudes toward food as well. Beard was likewise a gourmet and, as his show's title implied, a gourmand. Lucas was an adamant advocate of cooking as a means of creative expression. "The preparation of good food is merely another expression of art," she wrote in her Cordon Bleu Cook Book, "one of the joys of civilized living." ${ }^{, 13}$ The two cooking show hosts revered food, and on her program Lucas was fond of complimenting it with words like "beautiful," "rich," "delicious," and "delectable." "Easy" and "quick" were not among the adulations. She also spent a good portion of time on decorating and presentation of the dishes. For example, for her Hungarian goulash, she inserts bundles of blanched celery into green pepper rings, saying, "In France, they [do this] to garnish the goulash platter." (In contrast, on a 1950 episode of Chef Milani Cooks, the host prepares a salad composed of canned vegetables). ${ }^{14}$ While there were certainly groups who fell in line with this high-minded attitude toward culinary pleasures exhibited by Beard and Lucas - Gourmet magazine, after all, had been launched in 1941 - it was not one that most people saw on 
television or that most people of average means brought to fruition in their daily lives. It is, though, very much what we see on cooking television today - for instance, Giada De Laurentiis is especially prolific with sense descriptors - in addition to promises of "easy" and "quick."

Where there was a strong lobby for the professionalization of cooking and propagation of the idea that cooking was a science in the $1950 \mathrm{~s},{ }^{15}$ Lucas was firmly in the art camp. Her demeanor and attitude towards cooking went a long way toward removing cooking from the category of obligatory work altogether. While she ignored the art versus science debate on the surface, she mocked notions of precision instructing, for example, to add " $52 \frac{1 / 2}{2}$ grains of salt" or "7 1/4 grains of cayenne pepper."

Lucas displayed a notably different persona from her contemporaries as well as from today's cooking program hosts in yet another way. Her home economist peers, in addition to advocating simplicity and speed, seemed perennially concerned with making dishes that husbands and children would like. Nutrition by stealth and preparing meals that would have them clamoring for more were of great importance. Today's hosts are similarly concerned with getting children to eat healthfully as well as accommodating a variety of palates and diets, from those who can't tolerate milk to those who won't tolerate meat. Cooking for families and friends has always been a central end result of the instruction agenda. In today's cooking shows, we often see the actual recipients enjoying the fruits of labor, be it Nigella Lawson's children, Jamie Oliver's mates, Ina Garten's husband, or Emeril Lagasse's audience members. Even Julia Child, while usually alone at the dining table at the end of The French Chef, clearly had the intention of an imminent set of guests joining her. Lucas, however, was markedly alone during both the broadcast and in the presentation of her life. She occasionally mentioned a dinner party suggestion, something guests might like, and one time she alluded to a personal family member by saying that she invented iced tomato soup for her sister who loves tomatoes "in every form or 
shape." Otherwise, there was no sense of a family or friends with whom she would be sharing her meals.

Other than the knowledge that there was a camera crew and her occasional polite requests to off-camera staff, (e.g., "Would someone be so kind as to take this [dish, tablecloth, etc.]? Thank you very much.”), she embodied isolation. The lack of a back story rendered Lucas impersonal and created a sense of detachment from her viewers. ${ }^{16}$ It is paradoxical, too, that the show was titled after the host and revealed no hint as to its topic. She was not quite enacting the theatrical "aesthetic distance" that Lynn Spigel describes wherein an actor does not acknowledge the audience in order to create an illusion of reality. ${ }^{17}$ Lucas did address her audience warmly, including a genuine-seeming "goodbye and God bless you all" at the end of each show. Therein she exhibited the approach that makes a compelling broadcast performer: that intimate "parasocial" bond that makes the viewer/listener feel that she has a personal relationship with the TV persona. ${ }^{18}$ In today's cooking programs, that intimacy is broken by in-studio audiences and on-set visitors. Yet, in total, Lucas constructed a restricted relationship with her viewers by not sharing bits from her personal life. We, the viewers, then could not see ourselves reflected in her because she seemed remote and unreal. It was a private experience more than an intimate one.

In another way, too, Lucas limited and controlled her relationship with the audience. Lucas was cooking for no one, not even herself. She never tasted or ate the food on screen. She made the food to be admired. Though she had an air of self-satisfaction upon turning out a perfect crêpe or omelet, she only hinted at the food's pleasurable qualities. When she takes onion soup out of the oven, she says, "There is one of the very best hot soups, no matter what the weather." She gazes at it for a moment, puts it on the counter out of the way, then moves on to her next recipe. But just as in her goulash episode in which she hints at the benefits of mistakenly adding too much sour cream (kissing her fingers to indicate deliciousness), when adding cream 
to vichyssoise, she says, "Naturally, the recipe will say exactly how much cream. Now if you want a slightly better soup, look out of the window, talk, ask questions. Don't look at what you're doing because, if you do, then you add the exact amount. If you don't, then you add a little more, and it's all that much better. When you're making vichyssoise, you don't want to be at all Scotch with the cream." With no evidence of gourmandise on her part, she was a temptress.

As these examples indicate, Lucas does not fit neatly into either the category of food Puritanism (though her appearance, demeanor, and aforementioned personal distance might suggest this) or of food porn that Richard Magee describes, ${ }^{19}$ though pleasure was clearly an essential element to her. She wrote in her Cordon Bleu Cook Book, "Preparation of good food requires time, skill and patience, and the results mean the difference between eating to exist and the satisfaction derived from one of the major pleasures of life" ${ }^{, 20}$ Whether or not such pleasure was to be hers was undetermined. As a result, viewers were deprived of the sensation of seeing food cut into, the textures, and the host's experience of the taste. In this ascetic way, she was like her TV peers - the job consisted of preparation and completion, not the enjoyment of eating. Today's shows are about both the pleasure of creating as well as the consumption. Indeed, the genre now benefits from an expanded audience given that such a duality recruits people who eat - i.e., everyone - as well as people who cook.

As with any television program, each subsequent installment provides new information while repeating the rituals of the genre. With a cooking show, such repetition enables a viewer to build a store of knowledge about skills and recipes. The very purpose of a recipe and its instruction is replication on the part of the viewer. In addition, repetition also allows viewers to "get to know" a host by developing an ongoing relationship with someone who exhibits recognizable mannerisms and attitudes. As Horton and Wohl wrote in 1956, "The persona is the typical and indigenous figure of the social scene presented by radio and television..[who] offers, 
above all, a continuing relationship.".21 In current cooking shows, a host might say, "You remember last time we used butter instead of olive oil" or "You know me; I can't stand a messy countertop." ${ }^{22}$ Yet with Lucas, it is as if each episode is discrete, thus hindering potential intimacy with her viewers. In this way, she disobeys the commonly accepted role of the TV person as well as TV series form." ${ }^{23}$

While The Dione Lucas Show was shot for at least part of its run in the basement of her restaurant across the street from her New York City apartment, ${ }^{24}$ there is no mention of either on the show. Lucas was tightly shot on the kitchen set, providing no clues as to her location otherwise. "One of the ways in which a presenter's personality is inscribed in a programme is location," writes Niki Strange. ${ }^{25}$ Though typical of cooking shows of the time, there would later be frequent departures from the kitchen, beginning with Julia Child in the dining room and her and others' visits to food markets. Current programs that stay in studio often present the audience, which gives us a sense of place even if artificial. Still others display non-kitchen areas such as the garden, the cookbook library, the butcher shop, and so on. Even if the set is not the host's actual home, we can surmise that audiences today prefer to see a host as someone to whom they can relate and someone who lives a recognizable life. Because these are expectations that have developed over time, however, they may not have been missed in the days of Lucas et al.

These restrictive features of the performer-host of The Dione Lucas Show are an indicator of the era - public service broadcasting ${ }^{26}$ delivered by an authoritative, remote figure - as well as of her personality, which was revealed by her appearance, behavior, and mannerisms. Lucas wore clothes that appeared to be constraining - blouses buttoned up high, full skirts with many pleats. Her hair was tied back in a bun. Her movements were precise and efficient (belying her misgivings about exactitude). "Let's get ourselves organized," she says, seemingly to herself. 
One can see she enjoys her work and the satisfaction of a job well done. It is mesmerizing to watch her section an orange, roll out dough, flip a crêpe, or stretch strudel dough over an entire worktable, all carried out with economical, dexterous movements. She was, intentionally, an artist at work. In many episodes, she removes her "impedimenta," as she called them - rings, a watch - and fumbles each time to find the pocket in her pleated skirt. The simple repetition of this act gives the viewers a small glimmer of Lucas' personality. Not only does Latin come naturally to her, but also she must have some attachment to her impedimenta if she insists on wearing them to a production session and taking them off on camera.

While most cooking show hosts were certainly pleasant and charming enough, Lucas' personality was sui generis. She had a subtle, dry, intellectual sense of humor that she displayed seamlessly and casually. While other cooking programs in the 1950s employed humor as a primary feature - Chef Milani Cooks, Monty Margetts' Cook's Corner, Ernie Kovacs' Deadline for Dinner - they were more in line with the type of vaudeville-reminiscent humor found elsewhere on TV in the medium's early days. In 1970 (when Graham Kerr's Galloping Gourmet was aired in the U.S.), Lucas told newspaper reporter Aileen Snoddy, "There is no need to introduce buffoonery into cooking. ${ }^{27}$ Lucas' scholarly and genteel air was, to say the least, atypical for a cooking show. Her humor and intelligence were intertwined and were the most telling aspects of what may have been her true persona and the only hint of intimacy with the audience. She revealed these characteristics by the vocabulary and grammar she used, by the few stories she told, and by her subtle, clever quips. "It's a very capital recipe," she says, for example, of the onion soup, and she tells of its origins in relation to Louis Quatorze (not "the Fourteenth"). She explains how her lemon curd recipe is from a 1682 Yorkshire book: "In 1682 they had to do a lot of diddling with the heat and coal and the wood or whatever they used then, because it had to be cooked at a beautiful temperature. And I'm sure if they'd had the top burner 
heat control they would have had a marvelous time." This sentence encapsulates the essence of Lucas' TV persona because it displays how she effortlessly mingled her wit, sophistication, erudition, and, starkly, the performance of her role as spokeswoman. The latter may in fact begin to answer the question as to who confined and defined her persona. Was it Dione Lucas herself or another entity?

While she was seen as a television cooking teacher, she had an equally, if not more important role as a promotional conduit and saleswoman. Despite her show's eponymous title, it was not a vehicle to promote Dione Lucas but one to promote the appliances and utilities that she used. Text accompanying the show's introduction read: "To encourage the American housewife to enhance one of her most creative talents, by bringing glamour to the dinner table through artistry in the kitchen with the aid of GAS - the Modern Cooking Fuel."

Lucas began every program not by introducing herself (not only did she never eat, but she never uttered her own name on screen) but with "How do you do? Welcome to my beautiful Caloric gas kitchen." Lucas was at the service of the appliance, not the reverse (as, one might argue, is true in real home kitchens). Acting as a promoter/spokesperson, then, is added to the list of required tele-skills of a cooking show host. While this was true of her peers and to a much lesser degree her successors, Lucas took the role to a masterful level: in one episode, she holds a print ad for a Caloric gas range under a piece of an expertly stretched, transparently thin section of strudel dough and reads it aloud. In other cooking shows, the specter of pleasing or appeasing one's family was ever-present; in The Dione Lucas Show, the overseers were the gas companies and Caloric. The show was hers in name only. She effaced her own identity, most of the time saying "we" and "our" rather than "me" and "mine." She pushed the inanimate object, the male (as she deemed the stove, we will soon see) breadwinning stove to the fore while she was his supplicant. 
One representative sample from her Hungarian goulash episode illustrates the dynamic: "I'm going to show you a little trick that I think will help you, but first you have to do something. You have to go out and buy a gas range. [pause] That's gas with a capital G." She then demonstrates how to skin a tomato over gas flame. "Turn on your gas. Your beautiful blue fame." She never says "stove" but is always careful to say "gas range" and "gas refrigerator." In her salad episode, wherein she did not use the range, she still took pains to acknowledge it: "I hope that you are now the proud possessors of a Caloric gas range because then all your problems are solved no matter what you do." So while she did not wax enthusiastic about canned or frozen foods, she did so about the gas range.

Indeed, the gas range was omnipresent to the point of becoming a major character in the show. The camera zoomed in and paused on close-ups of the burner controls and range top regularly. It served alternately as Lucas' boss, sidekick, and icon, and Lucas consistently interacted with and praised her co-performer. "I don't know what you think, Mr. Caloric Gas range, but I think it's a pretty beautiful apple pie, and I think you'll agree with me." Though, not long after The Dione Lucas Show aired, viewers would witness on cooking programs examples of what Toby Miller calls "participant observation" or "voice of the people"28 with viewer standins, ${ }^{29}$ Lucas was as remote as possible from interacting with anyone other than her food, her range, and, tenuously, her viewers.

It is impossible to know if viewers watched The Dione Lucas for these commercial purposes, but the TV's consumption-education role may certainly have been at work. Given that many prime-time viewers were likely to include men and therefore even less likely to toil in the kitchen, ${ }^{30}$ however, the primary goal in watching Lucas was presumably for the performance aspect. While this is certainly true today, as many programs intentionally attract and retain viewers by featuring non-cooking aspects (i.e. interpersonal drama, competition, travel) and 
focusing on consumption over cooking, such was not the supposed intention in 1947. Lucas likely thought and hoped that her viewers would follow her recipe for strudel or Caesar salad and producers and sponsors hoped they would buy Caloric appliances.

Lucas' successor, Julia Child, had a keen sensibility of herself in this role. In her biography of Child, Laura Shapiro pays heed to the host's awareness of cooking itself as a performance:

Long before she cooked on television, she was aware of an audience - first her father and sister, impatient for breakfast as she frantically tossed pancakes and spilled coffee, and later the guests sitting politely in the living room, while she probed the beef with anguish and wondered if it was done, or overdone, or raw. As a bride she practiced and practiced the role she called "chef-hostess" until she could give a dinner party without a glitch, or at least without any glitch she couldn't smoothly mend, smiling and conversing all the while. ${ }^{31}$

Child herself made the connection between cooking and performance: "I always feel it is like putting on a performance, or like a live TV or theater - it's got to be right, as there can be no retakes, she told [her friend Avis DeVoto] in 1953, nearly a decade before she saw a television camera for the first time." 32

The performance was transformed when Child was before the camera: "'The cooking part went OK, but it was the performance of me, as talker and mover, that was not professional,' she told [Mastering the Art of French Cooking co-author Simone Beck]. Everything had to be done more slowly, she decided, as if she were under water." ${ }^{, 33}$ Child was thus aware of her role as performer and was uncomfortable with it. As a result, she revealed more of what appeared to be a truer, less mediated self on camera. "Julia had no gift for artifice: she could perform but she couldn't pretend," writes Shapiro. ${ }^{34}$ 
Where Child seemed to take a semi-objective, critical view of herself, I found no evidence of Dione Lucas' attitude or perspective on her own role in biographical or archival material. Others, though, were free with their opinions, which often conflicted: New York Times food writer Marian Burros referred to Lucas as a "great showman,", while cookbook author and James Beard collaborator Barbara Kafka said she had "no sense of theater., ${ }^{36}$ A New York WorldTelegram reporter wrote, "Although she has no theatrical training - and not a degree in anything - there is drama in every word she says, in every motion of her deft fingers. ${ }^{, 37}$ These contradicting opinions are no surprise given the paradox of Lucas. A viewer might detect that Lucas was aware of her role as performer, but she suppressed any flair. The showmanship was simply in her doing - she could not curb the expression of her talent. Despite her self-effacing behavior, Lucas appeared to be extremely comfortable in front of the camera, perhaps as a result of her extensive teaching experience. She also seemed as though she could pretend - whether or not she was calculated in doing so - and, as a result, viewers were deprived of her presumed actual self.

At the same time, Lucas was authentic with regard to her task. She did not pretend or promise that cooking was easy. As Signe Hansen writes of today's programs, "Cooking as a professional chef is the antithesis of easy and fun, and thus one of the distinctions that food TV often succeeds in concealing. ${ }^{, 38}$ While Lucas did not project the fun-easy message, she clearly indicated that it was worthwhile. In this way, too, she was a precursor to Martha Stewart who intones "It's a good thing" about all her domestic undertakings.

Stewart is known as a master of her domain, both real estate- and content-wise, and likewise, the title of this essay is redolent of Virginia Woolf who called on women artists to claim their own spaces. The title also evokes an image of Lucas as a woman business owner in a male-dominated field and as an isolated, private person. These varied meanings are fitting given 
the many contradictions embodied in Lucas. From one or more perspectives, she was autonomous and emancipated, but, on television, she was beholden and enslaved (reminiscent of the common phrases "slaving over a hot stove" or "chained to the stove"). At times, she asserted her preferences, as when she makes gnocchi and says, "We're going to do the French one because I like them best. No other reason," or "I like to eat my apple pie hot. I don't know about you." Performing off-screen, as a teacher and restaurateur, she was (theoretically) in control; onscreen, though in control of her physical gestures, she was not.

The many contradictions and contraventions personified by Lucas were not a hindrance to her popularity at the time of the program's broadcast. ${ }^{39}$ They were, however, an obstacle to her place in the collective memory. Lucas is largely forgotten by time and, despite her television longevity, written out of the more cursory cooking show histories. Beard and Lucas did not fit with the times and therefore are not a functional part of a tidy story of U.S. cultural history, whereas Child was fully emblematic of her period and is recalled as a matter of course.

While TV scholar John Hartley states that “" Art' is never an input into any creative endeavor; it is sometimes an output (received as art by an observer or a later age) and always contextual," ${ }^{40}$ this runs counter to what transpired with Dione Lucas. She strongly believed her creative endeavors to be art, but it was the observer who was liable to receive it (the output) as entertainment and/or instruction and later generations who either don't see it at all or view it as a historical lark. "This genre combines pedagogy with entertainment, and rather than focusing on the monotonous rhythms and drudgery of housework," writes Elizabeth Nathanson, "these contemporary programs transform the home into space of quotidian drama and spectacular commercial display." ${ }^{42}$ While The Dione Lucas Show had drama (the transformation of food) and commercial display (overt shilling for Caloric and gas), in its outward presentation and performance aspects, it was decidedly an artifact of yesteryear. 
While the genre of the television cooking program has survived for decades beyond The Dione Lucas Show, U.S. television audiences and the cultural place of food and cooking have noticeably evolved. Were Lucas alive and hosting a cooking show in the 2010s, her attitudes would dovetail more comfortably with her peers today than with her postwar peers. Citizens and viewers, it would seem, have ultimately come around to embrace the earnestness of the endeavor and the notion that cooking and food are conduits for self-expression and fulfillment. She would be less obliged to act as explicit product spokesperson. ${ }^{43}$ And she would be perhaps compelled to cultivate a different type of personality for television consumption. ${ }^{44}$ Current day food celebrities are mandated to have a multi-platform presence via TV, radio, cookbooks, memoirs, blogs, and websites. "There is no give without take, no action unobserved," writes Signe Hansen. "No action unperformed. ${ }^{, 45}$ Lucas lived during a time when such exposure and personal revelation was not necessary or expected.

In some profound ways, cooking shows and their hosts serve the same role today as they did more than a half-century ago - to teach, to entertain, and to sell - but in different proportions and with decades of changed and varying values reflected therein. Dione Lucas was one of the few cooking show hosts of her day who viewers may have watched just to watch, as many hosts are watched today (and about which a good number of nostalgic critics lament). While cooking is still a mere fact of domestic life or undesired chore for many, the gap between its labor or leisure aspects, at least among more middle and upper classes, has shrunk. We now rely on hosts not only to provide us with useful information, but perhaps even more so to inspire us. Lucas offered a new mode of self -expression to a pre-second wave feminist audience; Stewart offered old ways of self-expression to a postfeminist audience; and the present legions of hosts now offer a smorgasbord of ways of expression to everyone, including men, women, and children. Lucas is an unsung precursor to our current approach to food and cooking. 
-Kathleen Collins is a librarian and associate professor at John Jay College of Criminal Justice at the City University of New York.

\section{Acknowledgements}

The author would like to thank Joe Langhan for his help in preparing this article.

\section{Notes}

${ }^{1}$ Les Dames d'Escoffier New York chapter, program biographies for "A Food Film Forum," January 22, 1994. From Dione Lucas Papers, Schlesinger Library, Radcliffe Institute, Harvard University.

${ }^{2}$ Lucas also hosted Gourmet Club in 1958.

${ }^{3}$ Dione Lucas, The Cordon Bleu Cook Book (Boston: Little, Brown, 1947), x.

${ }^{4}$ Harvey A. Levenstein, Paradox of Plenty: A Social History of Eating in Modern America (New York: Oxford University Press, 1993), 143.

5 Jessamyn Neuhaus, Manly Meals and Mom's Home Cooking: Cookbooks and Gender in Modern America (Baltimore: Johns Hopkins University Press, 2003), 268.

${ }^{6}$ Elizabeth Nathanson, “As Easy as Pie: Cooking Shows, Domestic Efficiency, and Postfeminist Temporality," Television \& New Media 10, no. 4, 2009: 313.

${ }^{7}$ Nathanson, “As Easy as Pie,” 313.

${ }^{8}$ U.S. Bureau of Labor Statistics, "Changes in Women's Labor Force Participation in the 20th Century," http://www.bls.gov/opub/ted/2000/feb/wk3/art03.htm

${ }^{9}$ In a September 12, 1993 Chicago Tribune article, Stewart told reporter Cheryl Lavin, "What I've found is that even women working outside the home have a craving to spend time on their 
homes. It's what I call my backlash. They are responding favorably to do-it-yourself, do-it-athome, being creative."

${ }^{10}$ For example, Michèle Mattelart, Women, Media, and Crisis: Femininity and Disorder (London: Comedia Publishing Group, 1986); Tania Modleski, “The Art of Being Off-Center: Daytime Television and Women's Work," Tabloid: A Review of Mass Culture and Everyday Life 4 (1981):18-24; Robert Hammel Stewart, The Development of Network Television Program Types to January 1953. PhD diss., Ohio State University, 1955.

${ }^{11}$ Stewart, The Development of Network Television Program Types, 352.

${ }^{12}$ Air times varied according to market and changed within markets as well. The program was show during the day in some locations.

${ }^{13}$ Lucas, Cordon Bleu Cook Book, vii.

${ }^{14}$ Chef Milani Cooks episode, June 30, 1950, viewed at UCLA Film \& Television Archive.

${ }^{15}$ Marsha Francis Cassidy, What Women Watched: Daytime Television in the 1950s. (Austin: University of Texas Press, 2005), 134; Elaine Tyler May, Homeward Bound: American Families in the Cold War Era. (New York: Basic Books, 1988), 81.

${ }^{16}$ This dynamic may have played a part in her absence in collective memory, and such restrictions would likely not be welcomed in today's television climate. John Langer, John Ellis, James Bennett, Andrew Tolson and others have analyzed the centrality of personality in the formula and success of TV programming and audience reception.

${ }^{17}$ Lynn Spigel, Make Room for TV: Television and the Family Ideal in Postwar America (Chicago: University of Chicago Press, 1992), 143. 
${ }^{18}$ Donald Horton and R. Richard Wohl, "Mass Communication and Para-social Interaction: Observations on Intimacy at a Distance," Psychiatry 19, no. 3 (1956): 215.

${ }^{19}$ Richard M. Magee, "Food Puritanism and Food Pornography: The Gourmet Semiotics of Martha and Nigella," Americana 6, no. 2, 2007, http://www.americanpopularculture.com/journal/articles/fall_2007/magee.htm

${ }^{20}$ Lucas, Cordon Bleu Cook Book, x.

${ }^{21}$ Horton and Wohl, "Mass Communication and Para-social Interaction," 216.

${ }^{22}$ Frugal Gourmet Jeff Smith on PBS in the 1980s was particularly adept at establishing familiarity, and likewise Sara Moulton and Rachael Ray on the Food Network in the 1990s. ${ }^{23}$ Lucas' relative longevity in prime time even while defying TV convention may have been permissible at the time given TV's novelty, though there has been much scholarship subsequently on the potency of formula and especially narrative in series television. A few suggested readings include: "Broadcast TV Narration" chapter in John Ellis' Visible Fictions (London: Routledge, 1982); Jason Mittell's Genre and Television: From Cop Shows to Cartoons in American Culture (New York: Routledge, 2004); Jane Feuer, "Narrative Form in American Network Television," in High Theory/Low Culture: Analysing Popular Television and Film, ed. Colin MacCabe (Manchester: Manchester University Press, 1986), 101-114.

${ }^{24}$ Angelica Gibbs, "With Palette Knife and Skillet,” New Yorker, May 28, 1949, 50.

${ }^{25}$ Niki Strange. "Perform, Educate, Entertain: Ingredients of the Cookery Programme Genre," in The Television Studies Book, Christine Geraghty and David Lusted, eds. (New York: Arnold, 1998), 304.

${ }^{26}$ Due to the commercial drive underpinning U.S. television, it was a struggle from the start for American television to reconcile a public service model emulating that of the government- 
sponsored U.K. model and to strike a workable a balance with the Reithian "educate, inform, entertain" trinity. Serious-minded, factual, documentary-style programs (e.g. See It Now, Meet the Press) that strived to do so are nonetheless emblematic of the time period.

${ }^{27}$ Newspaper Enterprise Association, publication unknown, April 13, 1970.

${ }^{28}$ Toby Miller, "From Brahmin Julia to Working-Class Emeril: The Evolution of Television Cooking," in High-Pop: Making Culture into Popular Entertainment, ed. Jim Collins, (Malden, Mass: Blackwell Publishers, 2002), 84.

${ }^{29}$ Just a few other examples of viewer stand-ins include: Monty Margetts, host of Cook's Corner in Los Angeles in 1949; Sally Ogle, host of Everybody Cook in Los Angeles in 1967; Julia Child on her various programs when she interviewed master chefs; and Jacques Pépin and his daughter on Jacques Pépin's Kitchen: Cooking with Claudine.

${ }^{30}$ With regard to women and men as cooks, some stereotypical views prevailed. 1950s Creative Cookery show host Francois Pope told a Chicago Daily Tribune reporter On June 12, 1960, "Cooking is not a job or a chore, and women can more easily see this when men act as their teachers. The finest cooks in the world are men." Lucas herself told a Columbus Citizen reporter on October 19, 1954 that men make better cooks because "it's a taxing profession and one that requires strength and endurance.” And as Angelica Gibbs wrote in the New Yorker $(1949,36)$, "Mrs. Lucas regards men as superior to women around a kitchen, because she has found that they have no preconceived ideas of what they're about to do and show a good deal more imagination than women when they get around to doing it."

${ }^{31}$ Laura, Shapiro, Julia Child (New York: Viking, 2007), 96.

${ }^{32}$ Shapiro, Julia Child, 96-7.

${ }^{33}$ Shapiro, Julia Child, 100. 
${ }^{34}$ Shapiro, Julia Child, 101.

${ }^{35}$ Marian Fox Burros, Cooking for Comfort: More than 100 Wonderful Recipes that Are as Satisfying to Cook as They Are to Eat (New York: Simon \& Schuster, 2003), 172.

${ }^{36}$ Author's interview with Barbara Kafka, July 2004.

${ }^{37}$ Robert Prall, “TV's Galley Gals: Dione Lucas Abhors Jiffy Techniques in Cookery: Believes 'More Art and Less Chemistry’ Makes for Finer Cooking,” n.d., Dione Lucas Papers.

${ }^{38}$ Signe Hansen, "Society of the Appetite: Celebrity Chefs Deliver Consumers," Food, Culture $\&$ Society 11, no. 1, 2008: 58.

${ }^{39}$ In fact, her British accent turned out to be a boon, not a drawback (Gibbs 1949, 35).

40 John Hartley, Television Truths (Malden, MA: Blackwell Publishing, 2008), 161.

${ }^{41}$ Later generations would have had a limited chance to see the program when it, along with some other classic cooking shows (including The French Chef), was shown on the brand new Food Network in 1993.

${ }^{42}$ Nathanson, “As Easy as Pie,” 314.

${ }^{43}$ Product placement has evolved to a more integrated and often nuanced aspect of programming. Where Lucas and others would virtually pause in their activities to discuss a specific product, today's hosts brandish their instruments leaving the viewer to read the label or recognize the style and brand.

${ }^{44}$ While it is not a new idea to choose cooking show hosts based on personality in favor of cooking skills (to wit, Monty Margetts and Sally Ogle), today's hosts are chosen based primarily on personality.

${ }^{45}$ Hansen, "Society of the Appetite," 59. 